\title{
Photovoltaic Farms-Economic Efficiency of Investments in North-East Poland
}

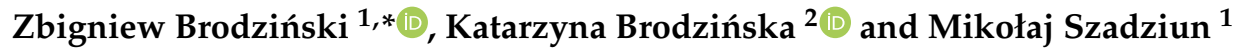 \\ 1 Department of Economic Competitiveness, Faculty of Economic Science, University of Warmia and Mazury \\ in Olsztyn, 10-719 Olsztyn, Poland; mikolaj@szadziun.pl \\ 2 Department of Agrotechnology and Agribusiness, Faculty of Agriculture and Forestry, University of Warmia \\ and Mazury in Olsztyn, 10-719 Olsztyn, Poland; katarzyna.brodzinska@uwm.edu.pl \\ * Correspondence: zbr@uwm.edu.pl; Tel.: +48-605-850-187
}

Citation: Brodziński, Z.; Brodzińska,

K.; Szadziun, M. Photovoltaic

Farms-Economic Efficiency of

Investments in North-East Poland.

Energies 2021, 14, 2087. https://

doi.org/10.3390/en14082087

Academic Editor: Algirdas Jasinskas

Received: 18 March 2021

Accepted: 6 April 2021

Published: 9 April 2021

Publisher's Note: MDPI stays neutral with regard to jurisdictional claims in published maps and institutional affiliations.

Copyright: (c) 2021 by the authors. Licensee MDPI, Basel, Switzerland. This article is an open access article distributed under the terms and conditions of the Creative Commons Attribution (CC BY) license (https:// creativecommons.org/licenses/by/ $4.0 /)$.

\begin{abstract}
The abandonment of conventional sources in favor of energy from renewable energy sources (RES) has a global dimension, and the dynamic increase in the share of energy from photovoltaic systems in the energy mix of many countries results from the possibility of obtaining it both on a small scale (micro-installations) and as part of economic investments (photovoltaic power plants). The study aimed to assess the economic efficiency of 22 photovoltaic farms located in northeastern Poland. The research covered 5 solar power plants with a capacity of up to $799 \mathrm{kWp}$ (I), 13 between 800 and $1100 \mathrm{kWp}$ (II), and 4 installations of $1.98 \mathrm{MWp}$ (III). The evaluation was based on net present value (NPV), internal rate of return (IRR), payback period (PP), profitability index (PI), accounting rate of return (ARR). Additionally, a sensitivity analysis was carried out regarding the value of economic indicators. The analysis shows that all studied PV farms are economically justified investments (NPV $>0$ ) regardless of the adopted scenario. Solar power plants of the largest analyzed capacity (group III) resulted in being the most profitable ones, but no linear relationship between the level of productivity and profitability was established. Due to the large variation in terrain shape in northeastern Poland, landscape value and social benefits, which are difficult to assess, the support system for investments regarding the construction of photovoltaic power plants proved to be the most effective in group I.
\end{abstract}

Keywords: photovoltaic power plant; energy management; cost analysis

\section{Introduction}

The increasing energy demand on a global scale and, at the same time, the introduced restrictions on emissions harmful to the environment and the climate are prompting the search for non-conventional energy sources, including renewable energy sources [1-8].

In the case of EU countries, the abandonment of conventional sources in favor of energy from RES results from the implemented concept of the European Green Deal (EGD), a plan to build a sustainable EU economy based on the challenges of combating climate and natural environment change $[9,10]$. The EGD, announced by the European Commission in December 2019, aims to reduce carbon emissions by $55 \%$ by 2030 and achieve carbon neutrality by 2050 [11]. The challenge facing the EU and thus all member states is turning this ambitious climate agenda into a success. It should, therefore, be anticipated that, despite the many problems and divergences in national and EU energy and climate policies, renewable energy will develop increasingly rapidly [7,12], with solar radiation energy becoming one of the main sources of energy generation. Solar energy is dispersed, difficult to use directly in practice, but its transformation methods are still being improved, which, combined with the introduction of economic incentives for systems using renewable energy sources (RES), further increases its importance [13].

Of all the methods for converting the sun's primary energy, two methods are commonly used, namely photothermal and photovoltaic conversion. Since the generation of 
power in those systems heavily depends on weather conditions, time of day and season, energy storage is a problem [7]. However, interest in solar energy harvesting is steadily increasing, with photovoltaic being the more favorable of the two solutions, in terms of both economics and practicality [14].

The dynamic growth of the share of energy from photovoltaic systems in the energy mix of many countries results from its undoubtedly pro-environmental advantages, such as lack of environmental pollution and other harmful consequences for the environment. Moreover, no noise is generated, and solar energy is converted directly into electricity [15].

Other advantages of photovoltaic installations are their fast implementation time and considerable adaptability to local conditions and needs [16]. Especially this last feature favors the development of micro-installations adapted to the needs of prosumers [17]. The most economically efficient use of solar energy is its total consumption by the user of the installation [18]. Therefore, for many small-scale, spatially distributed energy producers, the use of micro photovoltaic installations is an attractive solution $[19,20]$.

On the other hand, owners of photovoltaic power plants (those with higher capacity) sell all of the produced energy. In general, photovoltaic power plants are large-scale installations, which are technical infrastructure devices occupying large areas of land. In their case, the sun exposure associated with the terrain is important. In practice, this usually means that agricultural land must be taken out of production [21,22].

In countries where land for this type of investment is expensive and scarce and where favorable conditions related to solar insolation exist, solutions to combine agricultural production with electricity generation are increasingly being used [21,23-26]. This solution, referred to as agrovoltaics, involves the simultaneous land use for both PV and agricultural purposes. As observed, this innovative solution brings not only environmental but also economic benefits [24,25].

Due to the type of photovoltaic system, the way it is set up, the receiver of the energy produced, etc., photovoltaic farms can be defined as grid-connected, stationary, ground-mounted, commercial, profit-oriented from the sale of the produced electricity, commissioned, part of the technical infrastructure system of the area $[27,28]$.

On the technical side, photovoltaic farms also referred to as solar parks or solar power plants, are freestanding power plants with capacities ranging from $\sim 0.5 \mathrm{MW}$ to $\sim 50 \mathrm{MW}$, with the most common being 1-5 MW. The site of the power plant is in most cases fenced and monitored, and installations are connected to an online monitoring system that provides information on the current status and possible malfunctions of the system.

Despite numerous positive examples of the inclusion of solar farms in the energy mix, the photovoltaic conversion process used in energy production is far from perfect, as the efficiency of such installations is relatively low [29]. At the same time, research is being conducted to seek methods to increase the efficiency of traditional photovoltaic systems using, for example, optimized PV panel orientation [30,31], non-tracking plenary concentrators [32], panel cleaning systems [33], effective solutions to snow accumulation problems (at the material as well as architectural level) [34-36], a solution to reduce excessive panel heating [37-39], etc.

These multi-directional measures, together with falling installation costs and rising grid-supplied electricity prices, are making photovoltaics (PV) an increasingly economically advantageous source of electricity, even in geographical regions with less favorable insolation conditions [40].

Owing to the improvement of the transformation process, the acquisition of electricity from photovoltaics globally increased almost 17-fold between 2010 and 2018, with the growth rate being highest in Asia (55-fold increase) and Africa (40-fold). China is the largest producer of solar energy, with the production of 178,071 GWh in 2018, compared to only 730 GWh in 2010. In the European Union, solar energy production increased more than five times between 2010 and 2018, with both the amount produced and the growth rate varying within individual member states. In 2018, the highest amount of solar energy was produced in Germany, and it was 45,784 GWh (a 4-fold increase compared to 2010), in 
Italy-2266 GWh (an increase of almost 12 times). In Poland, energy production based on large-scale installations started in 2012, and only 1 GWh of energy was produced then. In the following years, it was 7 GWh-in 2014, 124 GWh-in 2016 and 300 GWh-in 2018. Thus the growth rate was very high (Renewable energy statistics 2020).

By following the trends, it can be seen that successive years have brought significant technological advances in the installation of photovoltaic power plants, and this initially slow process is gaining momentum and accelerating rapidly [41].

It is believed that the dynamics of the development of solar energy production is mainly determined by insolation conditions in individual regions [42], as well as the policy of financial support for investments in this field, the pro-environmental awareness of residents [13,43] and the way solar energy is being managed in the grid [44].

While the view that there is a growing public awareness of the role and importance of energy transition in environmental and climate protection efforts is not controversial [45-49], other aspects concerning the dynamics of the development of solar PV as an energy source are not so obvious anymore [50]. In many countries, research is being conducted on methodologies for identifying suitable locations for solar power plant installations [51,52], which are economically, socially or environmentally justified. In Poland, support for photovoltaic investments takes place in regions with the least favorable sunlight conditions, as well as an underinvested electricity grid and relatively easy access to agricultural land whose owners are willing to allocate it for non-agricultural purposes.

It can be considered that the efficient management of the development of photovoltaic power grid subsystems is hindered by, among others: long-term climate change, as well as local weather conditions [53], a solar activity that is difficult to predict [54,55], human activities and related emissions [56], large fluctuations in energy sale prices [57], agricultural land demand and land prices, quality and availability of electricity transmission infrastructure [44], renewable energy demand and incentives for solar farm operators [58], the quality of the power grid, or the characteristics of the installation that affect its productivity, such as the type of panels, sun exposure, shading and many other environmental elements [44,59-61].

Another important factor affecting the economic efficiency of photovoltaic power plants is the low level of electricity generation per year. It is estimated that the capacity of such installations may decrease by $20 \%$ in 25 years. This is an important reason to express the opinion that investing in photovoltaics, at current installation prices, without support is a high-risk venture [62]. At the same time, this risk and related concerns diminish as PV installation prices fall and the level of financial support for this type of investment increases [63].

In addition to the indicated factors, the dynamics of the sector's development in question will also be affected by the level and specificity of energy consumption, fully subordinated to its direct production [64]. For this reason, the "sectors coupling" is important, which aims, through the integration of different sectors, to make consumption independent from the supply of energy from renewable sources, e.g., through the development of modern energy storage systems. For this reason, a cost-effective solution may be considered the path of energy transformation based on the integration of energy production, storage and consumption processes [65-67].

Relatively high, as for the country's conditions, investment costs cease to be a decisive criterion for energy transformation [59]. The observed significant growth dynamics in the use of solar energy is the result of the financial support of the renewable energy sector implemented within the EU Community policy, as well as national policies [68,69], and the increasing energy efficiency of photovoltaic and solar installations [70,71]. Energy independence, diversification, stability of supply, or source of energy is also increasingly important for energy consumers. For these reasons, photovoltaics, as the only RES industry in Poland, was able to mobilize more investment capital than the entire conventional energy sector in 2019-2020, gaining the trust of both Polish and foreign equity investors, as confirmed by the IEO_PV stock index. 
It can be expected that the process of energy market changes-in favor of decentralized and dispersed renewable energy - will continue in Poland. The growing interest of investors in the production of energy from photovoltaic farms is justified by the dynamic development of PV technology, which is conducive to lowering investment costs per unit of energy produced and the tendency to increase electricity prices on the market [72,73].

On the other hand, factors, which are completely beyond the investor's control, such as meteorological conditions (mainly insolation), have a key impact on the efficiency of solar power plants. Although ex-ante analyses assume the level of insolation based on long-term meteorological data, these data are verified in practice only by active solar power plants.

Therefore, assessing the economic efficiency of operating farms provides important information for decision-making processes and evaluation of implemented solutions from both economic and social perspectives. This particularly concerns investment costs and investors' opinions on the evaluation of investment processes. The results are of preliminary nature and should be treated as such, as forecasts based on annual production results, especially in regions with less favorable insolation conditions, such as the northeastern part of Poland, may be burdened with a high error due to the short productivity monitoring period (a minimum period of five years would be optimal). Nevertheless, the ex-post analyses carried out are unique due to a large number of entities covered by the study, the possibility to compare investment costs within groups of solar power plants of different capacity and the forecasted scenarios of return on invested capital.

The structure of the paper includes an analysis of available statistical data on the development of the solar energy sector in Poland and characterization of the conditions of solar radiation in Poland. In the next part, the photovoltaic farms included in the study and the factors indicated by investors as decisive for their establishment were characterized. In the following section, the economic efficiency of the implemented investments is evaluated under different scenarios (pessimistic, base, optimistic). In the conclusion section, the results of the conducted analyses are synthesized both in the context of the assessment of economic efficiency of photovoltaic power plants and, more broadly, in the context of social benefits of investments subsidized with public funds.

\section{Materials and Methods}

The study aimed to assess the economic efficiency of photovoltaic farms operating in northeastern Poland. The region where the studied photovoltaic power plants are located is characterized by a low level of insolation compared to other parts of the country.

The subject of the research was the data obtained in direct interviews with 22 randomly selected investors. All participants represented special purpose vehicles (limited liability companies) managing their own photovoltaic farms. During the direct interviews, respondents were asked to provide information on investment costs, sources of financing, operating costs of the farms, and the scale of energy production and revenues. Opinions were also collected on the conditions affecting the undertaking and implementation of the investment. The installed capacity of the farms ranged from $0.48 \mathrm{MWp}$ to $1.979 \mathrm{MWp}$. The studied solar plants were in operation for at least one year, thus completing an annual production cycle. The analyzed facilities were commissioned at the turn of 2018-2019, which indicates that the investments' implementation took place in a similar period. Owing to the installed energy production monitoring systems, real data on production volumes was obtained.

In assessing the investment, in terms of its profitability, the following evaluation criteria were used:

- $\quad$ Net present value (NPV) allows investment projects to be assessed in relation to the primary objective of the company's operation, which is to maximize owners income by maximizing the value of the company. NPV is the difference between the sum of discounted future cash flows generated by a project and the value of the overall outlays; 
- Internal rate of return (IRR) shows the actual return rate on a photovoltaic farm over time. IRR shows the discount rate that makes the net present value (NPV) of all cash flows equal to zero in a discounted cash flow analysis;

- Payback period (PP) indicates the times it takes for the investment project to generate sufficient positive cash flow to cover the initial commissioning costs and any negative flows. The analyses assumed that an investment had been fully repaid once cumulative cash flow $(\mathrm{CCF})$ is positive and there are no negative CCFs afterward;

- Profitability index (PI) is a measure similar to the net present value (NPV) and is used, among others, in the analysis of the profitability of an investment project. This investment evaluation criterion is expressed as the quotient of the sum of discounted positive cash flows to the sum of discounted negative cash flows.

- Accounting rate of return (ARR) on investment, which is an indicator presenting the average accounting profit concerning the amount of incurred investment costs. It is the average annual net profit (sum of net profits divided by the project duration expressed in years) divided by the average annual investment understood as the sum of the initial and net final accounting value of the investment.

Furthermore, a sensitivity analysis regarding chosen critical parameters was carried out. The identified parameters were an annual increase in electricity sales prices and the level of inflation of goods and services. The sensitivity analysis was based on a combination of those parameters to represent various economic scenarios. Several scenarios were considered in terms of the approach to risks associated with solar plant operation. The conservative approach covers the uncertainty related to the future operation of the energy sector and potential economic downturns. An optimistic scenario represents the opposite view where the averaged out economic indicators are conducive to business development. Finally, the base scenario illustrates the most probable outcome, which follows the values of the parameters indicated in institutional forecasts (Energy Regulatory Office and National Bank of Poland forecasts.).

\section{Results and Discussion}

\subsection{Photovoltaics as an Energy Source in Poland}

Reports submitted to PSE SA (Polskie Sieci Elektroenergetyczne S.A.-state-owned transmission system operator in Poland) show that by 1 October 2020, the installed capacity of photovoltaics totaled $745.19 \mathrm{GWh}$, while as of 1 November 2020, one month later, the installed capacity of photovoltaics in Poland was 950.11 GWh TJ. This rapid increase in installed capacity is the result of cumulative investment processes.

Central Statistical Office data show that in 2015-2019 the total produced energy from photovoltaics was consumed in the country, and its growth rate, in the four-year period, was 2.7-fold. The use of photovoltaic energy in industry is gradually increasing, as evidenced by the fact that $56.67 \mathrm{GWh}$ of energy produced by photovoltaic systems was used for this purpose in 2015, which accounted for $9.8 \%$ of photovoltaic energy, in 2019 rose to 710.56 GWh TJ, which accounted for $45.9 \%$ of solar energy (Table 1 ).

The share of energy from photovoltaic installations in other sectors of the economy is increasing as well. The growth rate in the analyzed period, i.e., 4 years, was $62.65 \%$ (Table 1). As noted by other authors, the solar energy sector has attracted more than half of the investments related to the use of renewable energy sources [74].

The main direction of energy use from the photovoltaic market is its consumption by investors for their own needs. The largest share of prosumer PV energy is consumed in households. This was $79.22 \%$ in 2015 and $49.65 \%$ in 2019 , respectively. The total amount of energy obtained from solar systems increased 1.67-fold over the 4 analyzed years. The significant decrease in the share of photovoltaic energy used in households does not mean regression because quantitatively, the energy demand of households increased significantly (Table 1). 
Table 1. Solar energy balance in Poland 2015-2019.

\begin{tabular}{cccccc}
\hline Specification & \multicolumn{5}{c}{ Solar Energy Balance (GWh) } \\
\cline { 2 - 5 } & $\mathbf{2 0 1 5}$ & $\mathbf{2 0 1 6}$ & $\mathbf{2 0 1 7}$ & $\mathbf{2 0 1 8}$ & $\mathbf{2 0 1 9}$ \\
\hline Indigenous production & 578.65 & 729.90 & 796.65 & 959.81 & 1542.06 \\
Inland consumption & 578.65 & 729.90 & 796.65 & 959.81 & 1542.06 \\
Transformation sector, of which: auto-producer & 56.51 & 123.54 & 165.09 & 299.71 & 708.57 \\
electricity/combined heat and power plants & 522.15 & 606.35 & 631.56 & 660.09 & 70.36 \\
Final energy consumption, of which: & 63.71 & 68.14 & 68.42 & 67.87 & 769.73 \\
Commerce and public services & 458.44 & 538.21 & 563.14 & 58.63 \\
Households & &
\end{tabular}

Source: developed by the authors, based on CSO data (https://stat.gov.pl/obszary-tematyczne/srodowisko-energia/ (accessed on 3 March 2021).

It can be assumed that, outside of households, the vast majority of photovoltaic energy consumed has been produced in installations referred to as photovoltaic farms. The construction of a PV farm involves the need to carry out analyses in the target region to determine how much energy can be produced depending on the positioning of the panels and the local irradiation levels. Unfavorable environmental conditions can significantly reduce the amount of energy obtained from the installation.

The level of solar radiation in the country varies between 900 and $1200 \mathrm{kWh} / \mathrm{m}^{2}$. Figure 1 shows the area where the objects included in the study were located. This is a region where the average intensity of radiation is very low in relation to the rest of the country and is about $900 \mathrm{kWh} / \mathrm{m}^{2}$ (Figure 1).

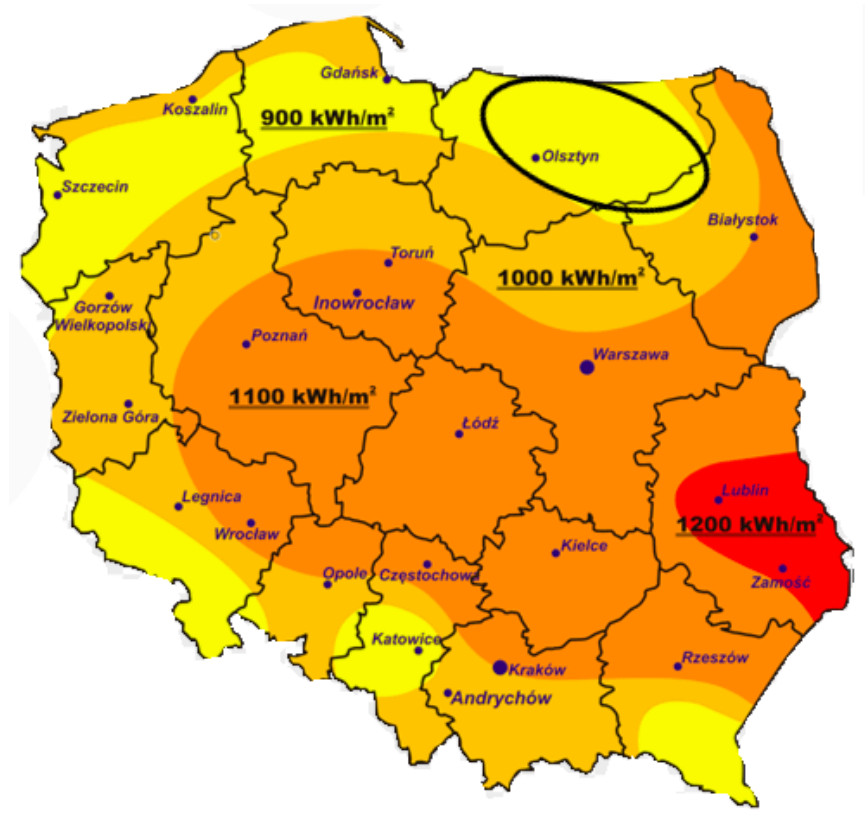

Figure 1. Map of solar radiation in Poland with marked study area. Source: http:/ /www.darsunsolar. $\mathrm{pl} /$ oferta/ (accessed on 5 March 2021).

Although Poland does not belong to areas with high solar radiation exposure, the conditions are similar to Germany, a country, which is considered a leader in the use of photovoltaics and thermal solar collectors [15].

\subsection{Characteristics of the Photovoltaic Farms Covered by the Research and the Conditions for Their Establishment}

The analyzed facilities had an installed capacity ranging from $480 \mathrm{kWp}$ to $1979 \mathrm{kWp}$. These types of installations (from $200 \mathrm{kWp}$ ) require carrying out economic activity in the field of producing electricity from renewable energy sources, as well as obtaining a 
concession under the terms and conditions specified in the energy law. These are on-grid installations cooperating with the power grid. Photovoltaic farms operate as part of a distributed energy generation system and owing to the connection to the public energy distribution system. They have a guaranteed sales continuity of the produced energy to the grid.

In the group of plants included in the analysis, 5 of them were classified in the group with the power of up to $799 \mathrm{kWp}$ (group I), another 13 farms had a capacity between 800 and $1100 \mathrm{kWp}$ (group II) and the 4 largest installations had the power of $1.98 \mathrm{MWp}$ (group III) (Table 2).

Table 2. Average power and productivity of the surveyed photovoltaic installations.

\begin{tabular}{cccccccc}
\hline \multirow{2}{*}{$\begin{array}{c}\text { Number of } \\
\text { Installations }\end{array}$} & \multicolumn{3}{c}{ Power of PV Farms (in kWp) } & \multicolumn{3}{c}{$\begin{array}{c}\text { Annual Productivity } \\
\text { (MWh/Year) }\end{array}$} & \multirow{2}{*}{$\begin{array}{c}\text { Energy Produced in MWh from } \\
\text { 1 kWp of Installed Capacity }\end{array}$} \\
\cline { 2 - 7 } & Average & Min. & Max. & Average & Min. & Max. & 1.01 \\
\hline 5 & 599.60 & 480 & 776 & 606.00 & 468 & 789 & 1.01 \\
13 & 999.54 & 975 & 1100 & 1012.85 & 978 & 1095 & 0.96 \\
\hline & 1979 & 1979 & 1979 & 1901.00 & 1895 & 1909 & \\
\hline
\end{tabular}

Source: developed by the authors, based on own research.

As it was observed, after the first year of operation, the highest productivity in relation to nominal power was obtained in groups I and II. Group I consisted of 5 installations with an average power of $599.6 \mathrm{kWp}$ and produced a total of $3030 \mathrm{MWh}$ of energy, which amounts to a yearly average of $606 \mathrm{MWh}$. Group II with 13 installations had an average power of $999.54 \mathrm{kWp}$ and produced an average of 1012.85 MWh of energy per year. For these two groups of power plants, the amount of energy produced from $1 \mathrm{kWp}$ of installed capacity was, on average, 1.01 MWh. However, in the case of the largest farms belonging to group III, observed productivity was lower. Those farms had an average installed capacity of $1979 \mathrm{kWp}$ and, on average, produced 1901 MWh of energy per year, which amounted to $0.96 \mathrm{MWh}$ per $1 \mathrm{kWp}$ of installed capacity. (Table 2).

A detailed analysis of the type and power of the panels and the component manufacturers does not allow developing a relationship between the quality of the equipment and the productivity of the systems installed using this equipment in different PV farms. As it was observed, due to the large variation in terrain shape in northeastern regions of the country, for PV farms occupying smaller areas, the locations (southern slopes, flat terrain) on which the structures with panels were placed were better selected.

When asked about their decisions regarding the choice of power plant capacity, investors most often planned to build farms with a capacity of approximately $1 \mathrm{MWp}$. In practice, the selection of the capacity of the installation resulted from arrangements with the operator and manager of the power grid regarding the available connection capacity of the power plant in the location indicated by the investor. When making decisions, operators strive to limit the so-called point load on power grids. As observed, the dispersed nature of this new form of energy supply infrastructure, such as photovoltaic farms, is consequently the result not so much of a deliberate strategy as of the poor condition of the medium voltage network, which has not been sufficiently upgraded over the years and therefore, determines energy consumption capacity.

Developing photovoltaic technology, as the only renewable energy source, is able to provide a package of benefits that minimize the very real risk of energy shortages, especially during the so-called summer peaks. It can also favor grid stability (http:// pses.eu/uploads/PDF/raport14.pdf (accessed on 14 February 2021)) The prerequisite for meeting these expectations would appear to be the intensification, in the short term, of modernization measures connected with the development of transmission infrastructure.

All of the facilities included in the study were put into operation in 2019-2020, and the investors obtained public funding for the implementation of the investments, due to which they were obliged to comply with the act-public procurement law. Therefore, the basic 
criterion for the selection of the contractor was the price. Owing to the similar conditions of the investments, it was possible to compare the actual investment costs, which were incurred in a similar period.

An analysis of the information obtained from the investors shows that in the case of installations with the lowest power of up to $799 \mathrm{kWp}$ (group I), the average construction cost of the installations was 2413.23 thousand PLN net and varied between 1775.37 thousand PLN and 3736.33 thousand PLN. In the case of installations between 800 and $1100 \mathrm{kWp}$ (group II), the average investment cost was 4238.97 thousand PLN net, and the average construction cost of the largest installations was 8140.63 thousand PLN net. In the case of the largest installations (group III), all of them had the same connection capacity, even though they belonged to different owners (Table 3).

Table 3. Average net cost of photovoltaic farm investment grouped by nominal power.

\begin{tabular}{cccc}
\hline \multirow{2}{*}{$\begin{array}{c}\text { Power of PV Farms in kWp } \\
\text { (Kilo Watt Peak) }\end{array}$} & \multicolumn{3}{c}{ Total Net Investment Cost (Thousand PLN) } \\
\cline { 2 - 4 } & Average Cost & Min. & Max. \\
\hline Group I (5 installations) & 2413.23 & 1775.37 & 3736.33 \\
Group II (13 installations) & 4238.97 & 3288.83 & 6049.88 \\
Group III (4 installations) & 8140.63 & 7979.80 & 8333.68 \\
\hline
\end{tabular}

Source: developed by the authors, based on own research.

When comparing the construction costs of photovoltaic farms, unit conversion per $1 \mathrm{kWp}$ of installed capacity was used. As the research shows, in the period of investment implementation (i.e., at the turn of 2018 and 2019), the lowest average cost of photovoltaic farm construction concerned the smallest analyzed installations, with the capacity of up to $799 \mathrm{kWp}$, and the largest ones (from group III). In the former case, it amounted to PLN 4024.74 net, and in the latter-PLN 4113.51 net per $1 \mathrm{kWp}$ of installed capacity. The most expensive farms to build were those with a capacity of around $1 \mathrm{MW}$, which is the most common in both the region and in the country. In this case, the average net investment cost per $1 \mathrm{kWp}$ of installed capacity amounted to PLN 4240.93 per $1 \mathrm{kWp}$ of installed capacity and was $4.2 \%$ higher than the average combined construction costs of the smallest and largest installations analyzed (Table 4).

Table 4. Cost structure and financing sources for the construction of photovoltaic farms included in the study.

\begin{tabular}{|c|c|c|c|c|c|c|}
\hline \multirow{3}{*}{$\begin{array}{l}\text { Average Values } \\
\text { per kWp (PLN) }\end{array}$} & \multicolumn{6}{|c|}{ Installation Capacity in $\mathrm{kWp}$} \\
\hline & \multicolumn{2}{|c|}{ Group I } & \multicolumn{2}{|c|}{ Group II } & \multicolumn{2}{|c|}{ Group III } \\
\hline & $\mathbf{N}$ & $\%$ & $\mathbf{N}$ & $\%$ & $\mathbf{N}$ & $\%$ \\
\hline Net installation cost & 4024.74 & 100.00 & 4240.93 & 100.00 & 4113.51 & 100.00 \\
\hline Subsidy amount obtained & 2277.68 & 56.59 & 2302.50 & 54.29 & 2587.79 & 62.91 \\
\hline Investment credit amount & 1142.38 & 28.38 & 1245.97 & 29.38 & 954.72 & 23.21 \\
\hline $\begin{array}{c}\text { Amount of } \\
\text { own contribution }\end{array}$ & 604.68 & 15.02 & 692.46 & 16.33 & 571.00 & 13.88 \\
\hline
\end{tabular}

Source: developed by the authors, based on own research.

According to European Photovoltaic Industry Association (EPIA) report, net prices of installations in the segment of ground-mounted photovoltaic farms up to $2.5 \mathrm{MW}$ have decreased over the past few years from a range of $1.22 € / \mathrm{W}-1.75 € / \mathrm{W}$ to between $0.98 € / \mathrm{W}$ and $1.45 € / \mathrm{W}$ (www.gramwzielone.pl/energia-sloneczna/4413/dachowe-inaziemne-elektrownie-fotowoltaiczne-ile-kosztuja-i-czy-nadal-beda-taniec (accessed on 1 February 2021)). Assuming an average NBP exchange rate in 2020 of 4.4459 PLN/1 $€$ (https:/ / eur-pln.pl/2020/ (accessed on 30 January 2021)), it can be seen that the prices of the installations covered by the analysis according to the three power ranges adopted were, 
respectively $0.905 € / \mathrm{W}$ for installations in the first group (up to $799 \mathrm{kWp}$ ), $0.954 € / \mathrm{W}$ in group II and $0.925 € / \mathrm{W}$ for the farms in the largest group.

According to the research, the highest level of support for investments, per $1 \mathrm{kWp}$ of installed capacity, was obtained by investors, who built power plants of the highest capacity (group III). The installations belonging to group II (from 800 to $1100 \mathrm{kWp}$ ), i.e., of the capacity for which grid operators most often give their consent, turned out to be the most expensive to implement and, at the same time, requiring the highest share of own funds (from own contribution and credit) (Table 4).

Investors in face-to-face interviews indicated that they were aware of this situation. However, the possibility to implement the investment was determined mainly by obtaining a grid connection permit from the operator, which indicates the maximum power of a photovoltaic power plant available for a given location.

The ground-mounted installations included in the analysis occupied, together with the land for accompanying infrastructure, an area ranging from 1.6 ha to 2.2 ha per $1 \mathrm{MWp}$ of installation capacity. The leased area for the farm, according to the respondents, depended on the planned size of the farm, local landform, as well as the terms of the agreement with the landowner (e.g., lease of the entire plot of land). Two cases were reported where a much larger solar installation was planned than the one implemented, and therefore, much larger areas of land were rented than those necessary for the installation of the solar panels.

When indicating the factors influencing investment decisions, research participants most often mentioned:

- Obtaining the grid operator's consent for a relatively large installation capacity, which is conducive to lowering unit investment costs;

- Obtaining support for investments-all the investors providing information had previously prepared a project for financial support, submitted it under regional operational program (ROP) and undertook investments after obtaining co-financing;

- Location with access to transmission lines and adjacent to a paved road;

- The amount of land rent-all the analyzed investments were developed on rented land with a lease period of min. 25 years (annual rent ranged from PLN 5 to 15 thousand per 1 ha);

- The possibility of selling the energy at a price, which would enable debt repayment over a period of 5 to 10 years.

The construction of a photovoltaic farm requires analyses in the target region to determine how much energy can be produced, depending on the location of the panels and the radiation reaching the facility. Less favorable conditions may slightly reduce the amount of the obtained energy - however, one cannot definitely conclude on the profitability of the investment only based on its geographical location (positioning of panels, angle of inclination or surrounding buildings). The irradiation value in the analyzed locations is approximately $900 \mathrm{kWh} / \mathrm{m}^{2}$. However, its precise determination at a given point is difficult based on meteorological maps.

In the case of investments concerning the construction of photovoltaic farms, in some regions of the country, including the region of northeastern Poland, a significant number of them have received support and are being implemented under the regional operational program (ROP), as well as from the funds of Bank Ochrony Środowiska (BOŚ S.A.), which offers bridge and supplementary credits to finance EU co-financed projects. The value of funds supplied by BOŚ S.A. cannot exceed either the total funds obtained from EU projects (bridge credit) or $90 \%$ of the project value (both credits combined). As indicated earlier, all of the analyzed PV farms received ROP support.

The interviewed farm owners declared that they were already planning further investments $(72.7 \%)$, including five of the 22 survey participants, who were in the process of preparing new projects. Furthermore, in the case of new projects, they declared that the solar farm equipment would be supplemented with energy storage facilities, which are a new and important element of the integration of photovoltaic systems with the grid. 


\subsection{Investment Determinants}

The basic criterion when deciding on an investment consisting of establishing a photovoltaic farm should be its profitability. According to statements made by investors, when assessing the profitability of the investment, they took into account multiple factors. The factors they most frequently identified were the level of obtained co-financing, the cost of connecting the installation to the grid (depending on the distance from the medium voltage grid), the expected sale price of electricity, the type of modules installed, their placement and the amount of land rent. Moreover, the main source of information on the rationality of the project was the opinions of other investors, who have already carried out similar investments. Site visits and interviews with owners of operational PV farms involved obtaining information on:

- Type and parameters of equipment and materials used in the course of investment;

- Formalities related to the execution of the investment;

- Contractors and costs of individual stages of the investment;

- Energy sales opportunities and prices.

When analyzing the investment processes, it was observed that the entire supply of the remaining elements of the solar power plant equipment (apart from PV modules), constituting about $28 \%$ of the total investment expenditures, were domestic products. In particular, domestic companies carried out labor related to the production and construction of structures (frames) for the modules. The high competitiveness of domestic suppliers and contractors of structures was related to the large-size nature of such system elements and the presence of a large group of companies with appropriate experience and production capacity in the country. The transformer stations and electrical cabling supplied to the power stations were also sourced from domestic manufacturers. On the other hand, smaller elements, such as fencing, the entrance to the power plant, preparation and clearing of the land for the power plant, were carried out by local subcontractors. Local companies were also responsible for connecting the power plant to the medium voltage grid.

As it was observed, investors were willing to provide information and share their experience gained during the investment process. This opinion refers both to the investors participating in the research and people from whom they sought information before starting their investments. This specific stage in the development of the industry consisting of the willingness of investors to share their knowledge and experience fosters its development, verifies the market of equipment and technology suppliers, and inspires the search for innovative solutions to improve the efficiency of solar energy production.

When assessing the performance of photovoltaic power plants, one can analyze their technical, social and economic efficiency. The article focuses on economic efficiency, which is one of the basic ways to evaluate the economic activities undertaken by an enterprise. To measure efficiency, an indicator approach was adopted, based on the indicators described in Chapter 2: net present value (NPV), internal rate of return (IRR), payback period (PP), profitability index (PI) and accounting rate of return (ARR). To determine the values of the indicators defined above, it was necessary to prepare cash flow forecasts for the studied photovoltaic power plants.

Average energy sales prices did not differ between the analyzed groups of producers. This means that an average entrepreneur managing a solar power plant with a capacity of up to $2 \mathrm{MW}$ does not have a favorable negotiating position regarding the price at which the produced energy is sold. Prices adopted by producers in the non-auction system, as this is the system in which investors could operate, are similar and reach a level of approximately PLN 245 net per 1 MWh of electricity supplied to the grid.

As part of the analysis of the economic efficiency of the investment related to the construction of a photovoltaic power plant, it was necessary to make assumptions regarding the price level in a horizon of 25 years, i.e., during the approximate lifetime of such an installation. For the purpose of the forecast, an average base annual increase in electricity sales prices provided to producers was assumed at the level of 2\% (Energy Regulatory Office forecast). In addition, a sensitivity analysis was carried out regarding the value of 
this parameter. The high level of dependence of the energy sector on the adopted policies and economic conditions makes it difficult to predict the growth rate of energy sales prices. The analyses covered three distinct scenarios: conservative, base and optimistic, with corresponding values in the range 1-3\% for annual energy prices increase over the installations' lifetime.

Photovoltaic installations, similar to other technical infrastructure devices, are characterized by an efficiency that gradually decreases over time. For the purpose of the long-term analysis, the rate of decline of the electricity generation efficiency level for the studied power plants was assumed to be constant at $0.7 \%$ per year. This is the average rate of efficiency loss declared by panel manufacturers.

Furthermore, respondents have pointed that a solar installation without its own energy storage must draw significant amounts of energy from the grid as part of its own consumption. This energy is used to keep the equipment in an active (operational) state to avoid switching equipment on and off at nonproductive times. In addition, energy drawn from the grid powers the plant's lighting system and condition monitoring equipment. Consumption of electricity for own use is relatively constant throughout the year. The energy demand does not change as the efficiency of the panels decreases over time. The costs associated with energy consumption were included in the operating costs. As it was observed, among the studied installations, the average energy consumption per year is 9.6 MWh per $1 \mathrm{MW}$ of installed capacity.

Debt in the form of credit creates costs for the company and is recognized as a financial cost in the analysis. This means that the loan has a negative impact on cash flow. The average annual installments over the duration of the loan are equal. Depending on the amount of invested credit, the companies were granted different interest rates. The average interest rate negotiated by companies running solar plants of the lowest capacity was 3.25\%, installations in group II negotiated an interest rate of 3\%. Companies with the photovoltaic power plant of the largest analyzed capacity were able to secure the lowest average interest rate of $2.75 \%$. The repayment period of 10 years was the same for every entity.

According to the information obtained from the investors, the operation of a freestanding photovoltaic power plant, apart from the costs of energy consumption for own needs, involves bearing operating costs, such as insurance, costs of servicing and cleaning the area around the panels, costs of land rent and accounting services, property tax and, optionally, costs of employment (introduced in projects that were awarded funding). For this group of costs, which affect the operating costs of the photovoltaic farm, an annual price increase of 3.03\% (National Bank of Poland Projection Data-3 year average 20212023) was assumed. Furthermore, this parameter was identified as crucial. Thus, it was included in the sensitivity analysis scenarios. The upper threshold value from the NBP inflation forecast of $3.2 \%$ was considered for the conservative scenario in contrast to the optimistic scenario, which assumed the bottom value of $2.8 \%$. In addition, other expenses had to be included in the analysis, i.e., income tax (19\% flat rate) and one-off replacement cost. The main one-off cost that is directly related to the operation of the power plant is the replacement cost. Photovoltaic inverter lifespan can vary depending on a number of factors. Heat, humidity, electrical components quality and frequency of maintenance are some of the most common causes for inverter failure. Most string inverter life expectancy ranges from 10 to 15 years. With proper and regular maintenance, it is even possible to extend this period by a couple of years. However, due to the difficulty associated with predicting the factors mentioned above, a common average life expectancy of 12 years was assumed for the solar inverters in the analyses. This assumption additionally ensures that the replacement cost is incurred only once during the lifecycle of the whole installation. The average cost of a set of inverters for a reference installation with a capacity of $1 \mathrm{MWp}$ is PLN 375 thousand. This amount was included in the forecast as a singular replacement cost incurred in year 12.

In addition, the preparation of the forecast involved the need to adopt a specific value of the discount rate. In each of the analyzed installations, the originally assumed value 
of the discount rate was adopted, which was indicated by investors during the process of preparing project documentation, making it possible to obtain co-financing. The information package for measure 4.1, "Support of generation and distribution of energy from renewable sources" implemented within the Regional operational program, recommends the use of a discount rate of $5 \%$, and thus this value was adopted in the analyses.

Table 5 shows the average values of the analyzed profitability assessment indicators for the specified three groups of PV farms, including those with an installed capacity of up to $799 \mathrm{kWp}, 800-1100 \mathrm{kWp}$ and about $2 \mathrm{MWp}$.

Table 5. Indicators for assessing the profitability of photovoltaic farms depending on the installed capacity-base scenario.

\begin{tabular}{|c|c|c|c|c|}
\hline \multirow[b]{2}{*}{ Indicator } & \multirow[b]{2}{*}{ Unit } & \multicolumn{3}{|c|}{ Nominal Power Groups of the Surveyed PV Farms } \\
\hline & & $\begin{array}{c}\text { Group I } \\
\text { Up to } 799 \mathrm{kWp}\end{array}$ & $\begin{array}{c}\text { Group II } \\
800-1100 \mathrm{kWp}\end{array}$ & $\begin{array}{l}\text { Group III } \\
1.98 \mathrm{MWp}\end{array}$ \\
\hline Net present value (NPV) & $(\mathrm{PLN})$ & $286,696.59$ & $491,320.53$ & $1,221,949.62$ \\
\hline $\begin{array}{l}\text { Payback period } \\
(\mathrm{PP})\end{array}$ & Years & 13.31 & 13.55 & 12.19 \\
\hline $\begin{array}{l}\text { Internal rate of return } \\
\text { (IRR) }\end{array}$ & $(\%)$ & $9.88 \%$ & $9.33 \%$ & $11.84 \%$ \\
\hline $\begin{array}{l}\text { Profitability index } \\
\text { (PI) }\end{array}$ & & 1.79 & 1.71 & 2.08 \\
\hline $\begin{array}{c}\text { Accounting rate of return } \\
\text { (ARR) }\end{array}$ & $(\%)$ & $14.33 \%$ & $13.82 \%$ & $16.25 \%$ \\
\hline
\end{tabular}

Source: developed by the authors, based on own research.

Analyzing the obtained results, it can be observed that regardless of the installed capacity of the photovoltaic power plant, all implemented investments were economically justified (NPV $>0$ ). According to the prepared forecasts, the shortest period of return of investors' money can be ensured by solar power plants of the highest studied capacity, belonging to group III. The average payback period in this group was 12.2 years. The investment payback period was longer for the smallest photovoltaic farms of group I, with a capacity of up to $799 \mathrm{kWp}$. Installations from group II, i.e., those for which permits are granted most often, are expected to recover the cost of the initial investment within 13.5 years (Table 5 ).

For each of the analyzed groups of solar farms, the analysis of the value of the internal rate of return (IRR) and profitability index (PI) confirms the advantageous position of solar power plants with the largest capacity as the most justified in terms of investment among the studied installations (Table 5).

The following sensitivity analysis was designed to indicate the possible directions of solar plant profitability regarding the outside economic factors. Two additional scenarios were considered. The conservative approach covered the uncertainty related to the long-term operation of the energy sector and potential economic instability. An optimistic scenario represented the opposite view where the averaged out economic indicators are conducive to the prolonged improvement of the economic situation of the studied companies.

To ensure the possibility of comparing the obtained results, it was necessary to weigh cumulative cash flow. The analysis uses the value of own contribution as a benchmark. The resulting indicator explains what multiple of own contribution solar plants have cumulatively generated for a given year.

Results presented in Figure 2 indicate that, regardless of the adopted economic scenario, the constructed solar plants were a reasonable investment in the long term. The worst-case scenario considered in the analysis recovered the initial expenses after 15 years. In contrast, the best-case scenario payback period for any type of solar plant was around 8.5 years. 


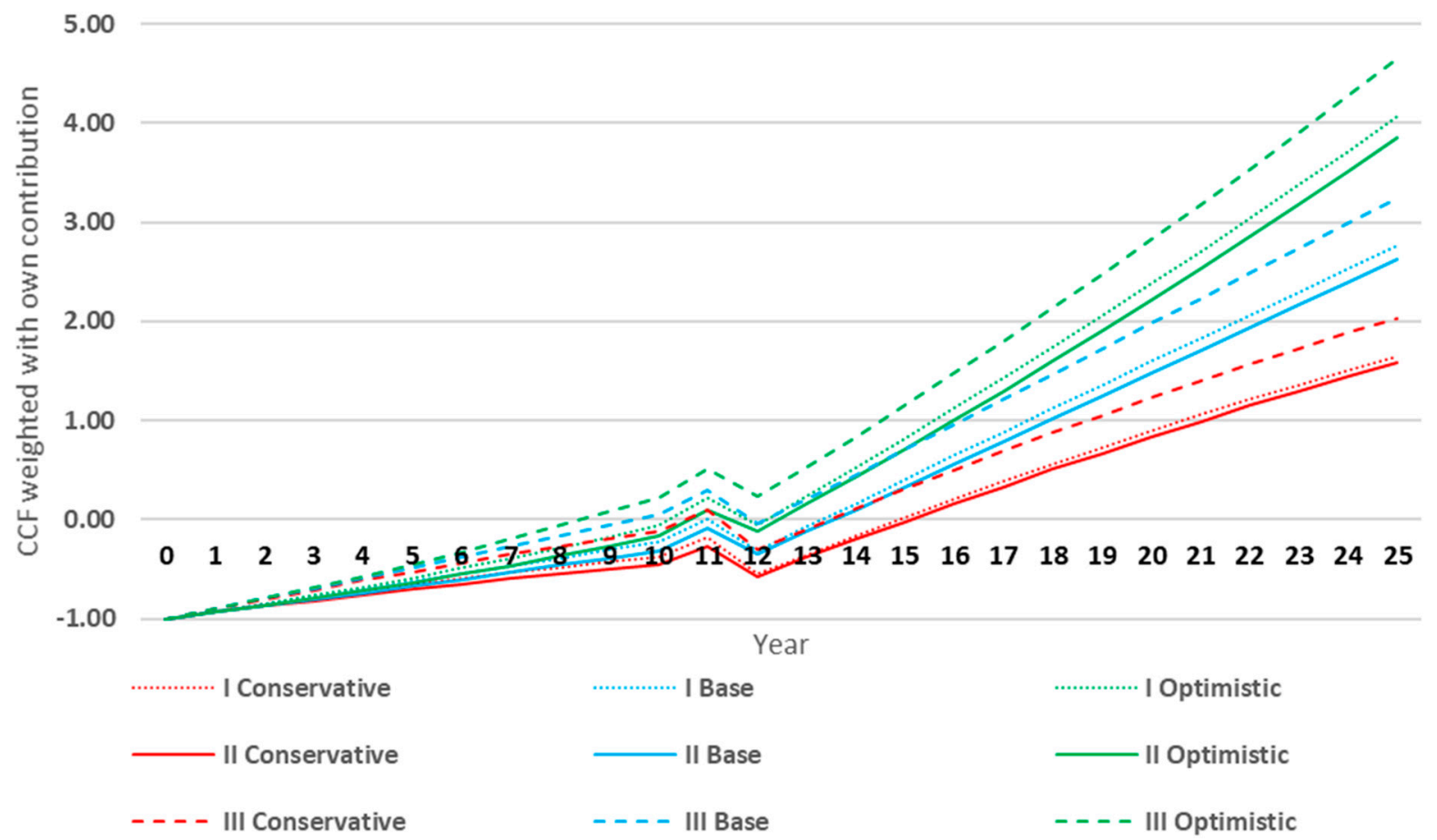

Figure 2. Cumulative cash flow weighted with the value of own contribution for analyzed scenarios. Source: own research.

To sum up, among the studied photovoltaic installations, the farms with the installed capacity of around $2 \mathrm{MW}$ were the most favorable in terms of investment return, i.e., those with the shortest average payback period and the highest return on the amount of own contribution. On the other hand, solar power plants with installed capacity ranging from $0.8 \mathrm{MWp}$ to $1.1 \mathrm{MWp}$ performed least well in terms of investment and economic return. It should be noted that the differences between the groups are insignificant. For example, between-group III, i.e., the farms with the highest investment efficiency, and group II of solar installations with the lowest profitability ratios, the accounting rate of return (ARR) indicator was 2.4 percentage points higher. Furthermore, several simplifications were made concerning the assumptions and values of individual parameters for the purpose of the analyses, which may be subject to some error. In addition, the renewable energy market is and will be significantly influenced in the future by national policies and socioeconomic conditions that are difficult to predict in view of the long-term effects of a global pandemic.

\section{Conclusions}

Photovoltaics is one of the fastest-growing RES technologies in Poland. As it has been observed, the use of photovoltaic energy in households is gradually increasing. Households are more frequently becoming prosumers and produce energy based on their own microinstallations. CSO data show high growth dynamics of photovoltaic energy, while data from the Polish power grid (PSE) show a significant increase in installed photovoltaic capacity, which only in the period of October-November 2020 increased by $27.5 \%$. This sharp increase in installed capacity is the result of cumulative investment processes in this period, related to the postponement of investment projects. Moreover, in the surveyed group of power plants, there were cases of investments that were qualified for financial support even three or four years before their implementation period.

The dynamic development of photovoltaic farms and the energy they produce is conducive to improving the overall security of the Polish power system (KSE). Photovoltaic farms, due to their spatial dispersion, do not cause point loads on the grid and reduce the costs of maintaining the so-called national power reserve.

According to the research, the solar plants of the lowest capacity (group I) turned out to be the cheapest per $1 \mathrm{kWp}$ of installed power. In the opinion of the entrepreneurs 
participating in the study, who conducted investment processes and currently manage photovoltaic farms, at the stage of investment implementation, cost differentiation may result in both from the price of the installed modules, and thus the applied technological solutions, and from the reduction of implementation costs (e.g., fencing, access road, etc.). The conducted analyses show that the unit energy productivity in group I and II is equal, although the installation cost per $1 \mathrm{kWp}$ is the highest in group II. However, at this stage of the research, it is difficult to assess whether and to what extent this is due to the quality, and thus the price, of the photovoltaic panels, and to what extent to the adjustment of the scale of the investment to the available spatial conditions.

Detailed analysis of the obtained data combined with participatory observation showed that one of the most important factors influencing the obtained results might be the more favorable location of smaller solar installations, which need less space, especially in areas with varied terrains, such as northeastern regions of Poland. It is also worth pointing out that smaller solar plants fit in better with the varied landscape, although this may be the subjective impression of the authors.

It is evident that all the photovoltaic farms included in the study are economically justified investments, as they were realized according to the investment projects and, moreover, they all received co-financing at the level of $54.29-62.91 \%$ of the total investment costs.

The conducted analyses show that investors in group III will obtain a total return on invested capital the soonest, i.e., after approximately 12 years, while in the optimistic scenario, it will be approximately 8.5 years, and after 13.5 years in the pessimistic one.

In conclusion, further development of photovoltaic power plants in regions with low insolation, such as northeast of Poland, without the possibility of obtaining co-financing, is only achievable if investment costs significantly decrease and/or energy sale prices increase. Without co-financing, even in the optimistic scenario, it is impossible for solar plants from any group to earn back their investment costs within 25 years. Therefore, the country's energy policy and support system for newly built power plants are crucial. Surveyed solar farms investors declared that they were already planning further investments $(72.7 \%)$, and several were already in the process of preparing new investment projects. Importantly, in the case of new projects, they declared that the solar farm equipment would be supplemented with energy storage facilities, which are a new and important element of the integration of photovoltaic systems with the power grid.

According to the authors, there are several arguments in favor of focusing financial support on the smallest power plants (group I), namely a smaller area is needed, and there is a possibility of better integration with the landscape, higher productivity in relation to the costs incurred, landscape values, and above all social benefits. The small scale of these power plants, with a high level of financial support, means that this group contains investors, who are the land owners on which the solar power plants are located.

Since the economic efficiency of solar power plants, at current investment costs and electricity prices for producers, depends on the level of subsidy, the mentioned social and environmental (landscape) benefits should be taken into account in the evaluation of publicly subsidized investment projects.

Author Contributions: Conceptualization, Z.B.; methodology, Z.B.; formal analysis, K.B. and Z.B.; data curation, Z.B., K.B., M.S.; writing-original draft preparation, Z.B., K.B.; writing review and editing, Z.B., K.B. All authors have read and agreed to the published version of the manuscript.

Funding: The results presented in this paper were obtained as part of a comprehensive study financed by the University of Warmia and Mazury in Olsztyn (grant No. 22.610.100-110).

Institutional Review Board Statement: Not applicable.

Data Availability Statement: Restrictions apply to the availability of these data. Data was obtained from business entities and are available from the authors with the permission of the studied business entities.

Conflicts of Interest: The authors declare no conflict of interest. 


\section{References}

1. Kurzak, L. Microinstallations Based on Renewable Energy Sources in the Construction Sector. In Proceedings of the World Multidisciplinary Civil Engineering-Architecture-Urban Planning Symposium (WMCAUS), Prague, Czech Republic, 14-18 June 2017; IOP Publishing Ltd.: Bristol, UK, 2017.

2. Sher, F.; Curnick, O.; Azizan, M. Sustainable Conversion of Renewable Energy Sources. Sustainability 2021, 13, 2940. [CrossRef]

3. Dovì, V.; Battaglini, A. Energy Policy and Climate Change: A Multidisciplinary Approach to a Global Problem. Energies 2015, 8, 13473-13480. [CrossRef]

4. Li, X.Y.; Cai, W.J.; Wang, C. Economic impacts of wind and solar photovoltaic power development in China. In Proceedings of the 8th International Conference on Applied Energy, Beijing, China, 8-11 October 2016; Volume 105, pp. 3440-3448.

5. Li, H.; Song, W. Characteristics of Climate Change in the Lancang-Mekong Sub-Region. Climate 2020, 8, 115. [CrossRef]

6. Loh, P.S.; Alnoor, H.I.M.; He, S. Impact of Climate Change on Vegetation Cover at South Port Sudan Area. Climate 2020, 8 , 114. [CrossRef]

7. Marks-Bielska, R.; Bielski, S.; Pik, K.; Kurowska, K. The Importance of Renewable Energy Sources in Poland's Energy Mix. Energies 2020, 13, 4624. [CrossRef]

8. Bukowski, M.; Majewski, J.; Sobolewska, A. Macroeconomic Electric Energy Production Efficiency of Photovoltaic Panels in Single-Family Homes in Poland. Energies 2021, 14, 126. [CrossRef]

9. Glavič, P.; Pintarič, Z.N.; Bogataj, M. Process Design and Sustainable Development-A European Perspective. Processes 2021, 9 , 148. [CrossRef]

10. Nikas, A.; Gambhir, A.; Trutnevyte, E.; Koasidis, K.; Lund, H.; Thellufsen, J.; Mayer, D.; Zachmann, G.; Miguel, L.; Ferreras-Alonso, N.; et al. Perspective of comprehensive and comprehensible multi-model energy and climate science in Europe. Energy 2020, 215, 119153. [CrossRef]

11. Sikora, A. European Green Deal-Legal and financial challenges of the climate change. ERA Forum 2021, 21, 681-697. [CrossRef]

12. Ma, J.; Oppong, A.; Acheampong, K.N.; Abruquah, L.A. Forecasting Renewable Energy Consumption under Zero Assumptions. Sustainability 2018, 10, 576. [CrossRef]

13. Alhammami, H.; An, H. Techno-economic analysis and policy implications for promoting residential rooftop solar photovoltaics in Abu Dhabi, UAE. Renew. Energy 2020, 167, 359-368. [CrossRef]

14. Szałata, Ł.; Siedlecka, A.; Lejkowski, C. Photovoltaic installations as the example of economy justified prosumer operations. Econ. Environ. 2016, 2, 190-205.

15. Majewski, J.; Szymanek, M. Technical, economic and legal conditions of the development of photovoltaic generation in Poland. Acta Energetica 2012, 2, 21-26.

16. Bigorajski, J.; Chwieduk, D. Analysis of a micro photovoltaic/thermal-PV/T system operation in moderate climate. Renew. Energy 2019, 137, 127-136. [CrossRef]

17. Bartecka, M.; Terlikowski, P.; Kłos, M.; Michalski, Ł. Sizing of prosumer hybrid renewable energy systems in Poland. Bull. Polish Acad. Sci. Tech. Sci. 2020, 68, 721-731.

18. Kruzel, R.; Helbrych, P. Analysis of the profitability of a photovoltaic installation in the context of sustainable development of construction. E3S Web Conf. 2021, 49, 00061. [CrossRef]

19. Abdmouleh, Z.; Gastli, A.; Ben-Brahim, L.; Haouari, M.; Al-Emadi, N.A. Review of optimization techniques applied for the integration of distributed generation from renewable energy sources. Renew. Energy 2017, 113, 266-280. [CrossRef]

20. Mitscher, M.; Rüther, R. Economic performance and policies for grid-connected residential solar photovoltaic systems in Brazil. Energy Policy 2012, 49, 688-694. [CrossRef]

21. Dinesh, H.; Pearce, J.M. The potential of agrivoltaic systems. Renew. Sustain. Energy Rev. 2016, 54, 299-308. [CrossRef]

22. Patel, M.T.; Khan, M.R.; Sun, X.; Alam, M.A. A worldwide cost-based design and optimization of tilted bifacial solar farms. Appl. Energy 2019, 247, 467-479. [CrossRef]

23. Dupraz, C.; Marrou, H.; Talbot, G.; Dufour, L.; Nogier, A.; Ferard, Y. Combining solar photovoltaic panels and food crops for optimising land use: Towards new agrivoltaic schemes. Renew. Energy 2011, 36, 2725-2732. [CrossRef]

24. Ainaducci, S.; Yin, X.Y.; Colauzzi, M. Agrivoltaic systems to optimise land use for electric energy production. Appl. Energy 2018, 220, 545-561. [CrossRef]

25. Lytle, W.; Meyer, T.K.; Tanikella, N.G.; Burnham, L.; Engel, J.; Schelly, C.; Peearce, J.M. Conceptual Design and Rationale for a New Agrivoltaics Concept: Pasture-Raised Rabbits and Solar Farming. J. Clean. Prod. 2021, 282, 11. [CrossRef]

26. Brudermann, T.; Reinsberger, K.; Orthofer, A.; Kislinger, M.; Posch, A. Photovoltaics in agriculture: A case study on decision making of farmers. Energy Policy 2013, 61, 96-103. [CrossRef]

27. Weschenfelder, F.; Leite, G.D.N.P.; da Costa, A.C.A.; de Castro Vilela, O.; Ribeiro, C.M.; Ochoa, A.A.V.; Araujo, A.M. A review on the complementarity between grid-connected solar and wind power systems. J. Clean. Prod. 2020, 257, 120617. [CrossRef]

28. Perez-Gallardo, J.R.; Azzaro_pantel, C.; Astier, S.; Domenech, S.; Aguilar-Lasserre, A. Ecodesign of photovoltaic grid-connected systems. Renew. Energy 2014, 64, 82-97. [CrossRef]

29. Chirila, A.; Buecheler, S.; Pianezzi, F.; Bloesch, P.; Gretener, C.; Uhl, A.R.; Fella, C.; Kranz, L.; Perrenoud, J.; Seyrling, S.; et al. Highly efficient $\mathrm{Cu}(\mathrm{In}, \mathrm{Ga}) \mathrm{Se}-2$ solar cells grown on flexible polymer films. Nat. Mater. 2011, 10, 857-861. [CrossRef]

30. Notton, G.; Lazarov, V.; Stoyanov, L. Optimal sizing of a grid-connected PV system for various PV module technologies and inclinations, inverter efficiency characteristics and locations. Renew. Energy 2010, 35, 541-554. [CrossRef] 
31. Oh, M.; Kim, J.-Y.; Kim, B.; Yun, C.-Y.; Kim, C.K.; Kang, Y.-H.; Kim, H.-G. Tolerance angle concept and formula for practical optimal orientation of photovoltaic panels. Renew. Energy 2021, 167, 384-394. [CrossRef]

32. Andrews, R.W.; Pollard, A.; Pearce, J.M. Photovoltaic System Performance Enhancement with Non-Tracking Planar Concentrators: Experimental Results and BDRF Based Modelling. In Proceedings of the 39th IEEE Photovoltaic Specialists Conference (PVSC), Tampa, FL, USA, 16-21 June 2013.

33. Micheli, L.; Fernández, E.F.; Aguilera, J.T.; Almonacid, F. Economics of seasonal photovoltaic soiling and cleaning optimization scenarios. Energy 2021, 215, 9. [CrossRef]

34. Heidari, N.; Gwamuri, J.; Townsend, T.; Pearce, J.M. Impact of Snow and Ground Interference on Photovoltaic Electric System Performance. IEEE J. Photovolt. 2015, 5, 1680-1685. [CrossRef]

35. Andenaes, E.; Jelle, B.P.; Ramlo, K.; Kolås, T.; Selj, J.; Foss, S.E. The influence of snow and ice coverage on the energy generation from photovoltaic solar cells. Solar Energy 2018, 159, 318-328. [CrossRef]

36. Niechaj, M. Effective use of photovoltaic systems i polish conditions. J. Ecol. Eng. 2016, 17, 147-154. [CrossRef]

37. Adibpour, S.; Raisi, A.; Ghasemi, B.; Sajadi, A.R.; Rosengarten, G. Experimental investigation of the performance of a sun tracking photovoltaic panel with Phase Change Material. Renew. Energy 2021, 165, 321-333. [CrossRef]

38. Ahmed, S.; Li, Z.; Ma, T.; Javed, M.S.; Yang, H. A comparative performance evaluation and sensitivity analysis of a photovoltaicthermal system with radiative cooling. Solar Energy Mater. Solar Cell. 2021, 221, 10. [CrossRef]

39. Hu, M.K.; Guo, C.; Zhao, B.; Ao, X.; Suhendri; Cao, J.; Wang, Q.; Riffat, S.; Su, Y.; Pei, G. A parametric study on the performance characteristics of an evacuated $\mathrm{fl}$ at -plate photovoltaic/thermal (PV/T) collector. Renew. Energy 2021, 167, 884-898. [CrossRef]

40. Branker, K.; Pathak, M.J.M.; Pearce, J.M. A review of solar photovoltaic levelized cost of electricity. Renew. Sustain. Energy Rev. 2011, 15, 4470-4482. [CrossRef]

41. Feldman, D.; Barbose, G.L.; Margolis, R.; Bloinger, M.; Chung, D.; Fu, R.; Seel, J.; Davidson, C.; Wiser, R.H. Photovoltaic System Pricing Trends: Historical, Recent, and Near-Term Projections I Electricity Markets and Policy Group. 2015. Available online: https:/ / emp.lbl.gov/publications/photovoltaic-system-pricing-trends-1 (accessed on 2 February 2021).

42. Gembarzewski, O.; Wrobel, K. Comparison of investment efficiency of selected PV farms in Bulgaria. Rocznik Ochrona Srodowiska 2016, 18, 1025-1038.

43. Argentiero, A.; Bollino, C.A.; Micheli, S.; Zopounidis, C. Renewable energy sources policies in a Bayesian DSGE model. Renew. Energy 2018, 120, 60-68. [CrossRef]

44. Eleftheriadis, I.; Anagnostopoulou, E. Identifying barriers in the diffusion of renewable energy sources. Energy Policy 2015, 80, 153-164. [CrossRef]

45. Kim, H.; Park, S.; Lee, J. Is renewable energy acceptable with power grid expansion? A quantitative study of South Korea's renewable energy acceptance. Renew. Sustain. Energy Rev. 2021, 139, 10. [CrossRef]

46. Keramitsoglou, K.M.; Mellon, R.C.; Tsagkaraki, M.I.; Tsagarakis, K.P. Designing a logo for renewable energy sources with public participation: Empirical evidence from Greece. Renew. Energy 2020, 153, 1205-1218. [CrossRef]

47. Karasmanaki, E.; Tsantopoulos, G. Exploring future scientists' awareness about and attitudes towards renewable energy sources. Energy Policy 2019, 131, 111-119. [CrossRef]

48. Karytsas, S.; Theodoropoulou, H. Socioeconomic and demographic factors that influence publics' awareness on the different forms of renewable energy sources. Renew. Energy 2014, 71, 480-485. [CrossRef]

49. Roddis, P.; Ziv, G.; Dallimer, M.; Carver, S.; Norman, P.D. The role of community acceptance in planning outcomes for onshore wind and solar farms: An energy justice analysis. Appl. Energy 2018, 226, 353-364. [CrossRef]

50. Korsavi, S.S.; Zomorodian, Z.S.; Tahsildoost, M. Energy and economic performance of rooftop PV panels in the hot and dry climate of Iran. J. Clean. Prod. 2018, 174, 1204-1214. [CrossRef]

51. Haddad, B.; Díaz-Cuevas, P.; Ferreira, P.; Djebli, A.; Pérez, J.P. Mapping concentrated solar power site suitability in Algeria. Renew. Energy 2021, 168, 838-853. [CrossRef]

52. Leirpoll, M.E.; Naess, J.S.; Cavalett, O.; Dorber, M.; Hu, X.; Cherubini, F. Optimal combination of bioenergy and solar photovoltaic for renewable energy production on abandoned cropland. Renew. Energy 2021, 168, 45-56. [CrossRef]

53. Canales, F.A.; Jadwiszczak, P.; Jurasz, J.; Wdowikowski, M.; Ciapała, B.; Kaźmierczak, B. The impact of long-term changes in air temperature on renewable energy in Poland. Sci. Total Environ. 2020, 729, 21. [CrossRef]

54. Zhu, J.; Cui, Y. Photovoltaics: More solar cells for less. Nature Mater. 2010, 9, 183-184. [CrossRef]

55. Yao, W.; Zhang, C.; Wang, X.; Zhang, Z.; Li, X.; Di, H. A new correlation between global solar radiation and the quality of sunshine duration in China. Energy Convers. Manag. 2018, 164, 579. [CrossRef]

56. Baranes, E.; Jacqmin, J.; Poudou, J.C. Non-renewable and intermittent renewable energy sources: Friends and foes? Energy Policy 2017, 111, 58. [CrossRef]

57. Hammond, G.; Hassan, A.H.; Craig, I.J.; Winnett, A.B. Whole systems appraisal of a UK Building Integrated Photovoltaic (BIPV) system: Energy, environmental, and economic evaluations. Energy Policy 2012, 40, 219-230. [CrossRef]

58. Rodrigues, S.; Coelho, M.B.; Cabral, P. Suitability Analysis of Solar Photovoltaic farms: A Portuguese Case Study. Int. J. Renew. Energy Res. 2017, 7, 243-254.

59. Ceran, B.; Szczerbowski, R. Techno-economic analysis of a photovoltaic installation. Bull. Miner. Energy Econ. Res. Institute Pol. Acad. Sci. 2017, 98, 15-26.

60. Janke, J.R. Multicriteria GIS modeling of wind and solar farms in Colorado. Renew. Energy 2010, 35, 2228-2234. [CrossRef] 
61. Leonarczyk, J. Results of the seasonal study on energetic output of photovoltaic installation with $668 \mathrm{~W}$ peak power. Problems Agric. Eng. 2013, 1, 151-160.

62. McHenry, M.P. Are small-scale grid-connected photovoltaic systems a cost-effective policy for lowering electricity bills and reducing carbon emissions? A technical, economic, and carbon emission analysis. Energy Policy 2012, 45, 64-72. [CrossRef]

63. Talavera, D.L.; Nofuentes, G.; Aguilera, J. The internal rate of return of photovoltaic grid-connected systems: A comprehensive sensitivity analysis. Renew. Energy 2010, 35, 101-111. [CrossRef]

64. Wójcicki, R.; Dębowski, K. The impact of prosument photovoltaic Installations on Shaping the profile of the power demand in Poland. ELEKTRYKA 2017, 3-4, 243-244.

65. Vinel, A.; Mortaz, E. Optimal pooling of renewable energy sources with a risk-averse approach: Implications for US energy portfolio. Energy Policy 2019, 132, 928-939. [CrossRef]

66. Wiśniewski, G.; Tokarczyk, P.; Pietrzak, P.; Michałowska-Knap, K. Możliwości Inwestycyjne w Energetyce Odnawialnej w Ramach Zgodnych z Europejskim Zielonym Ładem. 2020. Available online: http://konfederacjalewiatan.pl/aktualnosci/2020/1/_files/ 2020_09/ieo_final_1_.pdf (accessed on 6 February 2021).

67. Gudmundsson, O.; Thorsen, J.E.; Brand, M. The role of district heating in coupling of the future renewable energy sectors. Energy Procedia 2018, 149, 445-454. [CrossRef]

68. Selder, K. Renewable Energy Sources Act and Trading of Emission Certificates: A national and a supranational tool direct energy turnover to renewable electricity-supply in Germany. Energy Policy 2014, 64, 302-312.

69. Cansino, J.M.; Pablo-Romero, M.P.; Román, R.; Yñiguez, R. Promoting renewable energy sources for heating and cooling in EU-27 countries. Energy Policy 2011, 39, 3803-3812. [CrossRef]

70. Kuchmacz, J.; Mika, Ł. Description of development of prosumer energy sector in Poland. Energy Policy J. 2018, $21,5-20$.

71. Gradziuk, P.; Gradziuk, B.; Us, A. PV Power Plants Sector-Investment Costs Trends. Annal. Pol. Assoc. Agric. Agribus. Econ. 2018, XX, 44-49. [CrossRef]

72. Paska, J.; Surma, T. Electricity generation from renewable energy sources in Poland. Renew. Energy 2014, 71, 286-294. [CrossRef]

73. Piotrowska-Woroniak, J.; Woroniak, G.; Załuska, W. Energy production from PV and carbon reduction in great lakes region of Masuria Poland: A case study of water park in Elk. Renew. Energy 2015, 83, 1315-1325. [CrossRef]

74. Šály, V.; Packa, J.; Perný, M.; Andráš, M.; Tomica, J. Photovoltaic module structure under the high DC voltages stress. Mater. Methods Technol. 2021, 14, 9-18. 